Marina Dabic, Davor Vlajcic, Ivan Novak, (2016) "Entrepreneurial management education needs in the Republic of Croatia, Poland and the United Kingdom", International Journal of Educational Management, Vol. 30 Iss: 6 , pp.738 - 755

\title{
ENTREPRENEURIAL MANAGEMENT EDUCATION NEEDS: CASES OF THE REPUBLIC OF CROATIA, POLAND AND THE UNITED KINGDOM
}

\section{Introduction}

The globalization of higher education markets presents a complex challenge for management education particularly for those business schools attempting to compete in the global marketplace. Business schools are shifting from monodisciplinary topic approach to multidisciplinary approach while attempting to develop a global mindset through management diversity. Thus, invention and innovation processes involve highly interdependent teams that are long in duration, which makes them complex and increasingly more ambiguous. Building and sustaining knowledge and creative capacities for global operations is a critical challenge for most universities. To achieve that goal almost every country in the OECD has substantially increased its spending on education over the same period and launched multiple initiatives to spend this money more effectively. Meeting the challenges requires changes in cognitive processes through which managers frame business problems and adopting the set of attitudes that is often described as the global mindset (Barber Donnelly and Rizvi 2013).

Kaplan (2014) raises a more general question, one that is particularly salient in The European Management Journal asking "Is there even such a thing as 'European management",? And if so, what unique knowledge should Europe's business schools impart to future European managers? In an attempt to recognize a turning point in the European business school landscape and the beginning of Europe's (re)emancipation from the domination of US-style business schools the year 1997 seems a crucial point since it marks the establishment of the European Quality Improvement System (EQUIS) accreditation system - thus, opening genuinely global opportunities.

There have also been attempts to achieve avant-garde, novelty and a higher level of added value and enterprise and entrepreneurship within the Higher Education (HE) (European commission 2012, Gibb, (2002; Gibb et al. 2012 ). The impacts of management education on firms' strategies have been influenced by numerous different interests, and political and social factors, such as social values or corporate or organizational goals. A strategy, once determined, is evident in its articulation, choice, implementation and control. As this is a structural process, many questions arise, such as, what changes are required in the corporate structure and processes on one side and in management education on the other to create and enliven new more creative identities? It is assumed that competition and networking itself are a relational and a socially constructed concept that only makes sense when key decisionmakers engage in international comparison. 
We endeavor to contribute to the current debate on the role of management education through both macro and micro approaches in discussing the role of business schools in fostering innovation and particularly in implementing innovative approaches in different entrepreneurial sectors across countries. Horizon 2020 focuses on turning scientific breakthroughs into innovative products that provide opportunities for businesses as well as for the wider society. The rationale behind this is that "Europe's future economic growth and the employment of its citizens will depend on innovation in products, services and business models"1.

\section{Literature review}

This paper and the research upon which it is based adopts the Department for Business, Innovation \& Skills, 2013:15 definition: 'Enterprise education is the application of creative ideas and innovations to practical situations with enterprise education aiming to produce individuals with the mindset and skills to respond to opportunities, needs and shortfalls, with key skills including taking the initiative, decision making, problem solving, networking, identifying opportunities and personal effectiveness. Enterprise provision can be applied to all areas of education, extending beyond knowledge acquisition to a wide range of emotional, social, and practical skills. Entrepreneurship education is the application of enterprise skills specific to the creation and growth of organizations, with entrepreneurship education focusing on developing skills and applying an enterprising mindset in the specific contexts of setting up a new venture, developing and growing an existing business, or designing an entrepreneurial organization'.2

\section{Management education and needs of SME}

The relationship between universities and local SMEs presents a great leverage for knowledge transfer between these two entities (BIS, 2010). The research conducted by NESTA (2008) points out that strong links between higher education and industry can result in newly added value, innovative and entrepreneurial graduates, as well as in improvements in technical development, product innovation and business development. The importance of enterprises and entrepreneurship for future development is undeniable considering that SMEs generally account for approximately $95 \%$ of a country's economy (Shaw and Allen, 2006). Therefore, the long-term objective of business schools has increasingly been to become more involved in regional economic and social development through closer business and industry collaboration, such as management and leadership education programs (Darabi and Murray, 2012). This has resulted in the changing role of the higher education sector. Nowadays, for the purpose of economic development, universities are becoming more entrepreneurial as they commercialize their knowledge (Smith, 2000 in Marzo-Navarro et al., 2009). The university's role has traditionally been viewed as a support structure for innovation streaming mainly to provide the industry with trained personnel, research results, and knowledge. However,

\footnotetext{
${ }^{1}$ http://ec.europa.eu/research/participants/data/ref/h2020/wp/2014_2015/main/h2020-wp1415societies_en.pdf

${ }^{2}$ http://www.nao.org.uk/wp-content/uploads/2013/07/BIS-SUSTAINABILITY-BRIEFING_17-07_Final-2.pdf
} 
recently the trend has been changed and universities have embraced a different role establishing firms often based on new technologies originating from academic research (Etzkowitz, 2003; Etzkowitz, Ranga, Dzisah 2012). Increased globalization processes followed by rapid changes in competition and innovation processes promoted the need for the creation of stronger links between research communities and commercial enterprises (Plewa et al., 2005). The above mentioned situation has created space for development of serious models which will explain how universities/business schools close the gap of market needs? One of the most cited models is the Triple Helix model which stipulates that innovations are products of cooperation among universities, companies and governments (Etzkowitz, 2003). However, it is worth noting that the mentioned model has its opponents. In their research Viale and Campodall'Orto (2002) mention that this kind of model presents a threat to academic freedom and that it apprehends the space of education as the primary function of the university. If the major feature of the relationship between universities/business schools and companies is the creation and development of skilled labor force, technical consultancy services and even business start-ups - often in high-technology fields (Benneworth, 2001 Phusavat et.al, (2012) - then inflation of unnecessary labor would be avoided and pressure on labor market would be reduced. This kind of approach emphasizes that the university industry interface is a pillar that underpins knowledge-based economic development. In his article Hormann (1990, page 10) states:

"Business, the motor of our society, has the opportunity to be a new creative force on the planet, a force which could contribute to the well-being of many."

Over the last fifty years business schools have lived through a prosperous period of their lives, and now they have reached the crossroads of development (Pfeffer and Fong, 2002). Ivory et al. (2006), arguing that business schools as successful business has come to an end, point to many threats that this business is facing currently. For Cornuel (2005) the biggest threat lies in the dichotomy between the business requirements, i.e. the business reality, and the business schools' offer. His findings are supported by GRLI (2005, page 14):

"We have built a weird, almost unimaginable design for (business) education that distorts those subjected to it into critters with lopsided brains, icy hearts and shrunken souls."

Researchers agree that business school courses place too strong emphasis on quantitative management skills and techniques (Hawawini, 2005; Mitroff and Denton, 1999). Further on, Mintzberg's (2005) research on the effectiveness of MBA programs found evidence pointing to heavy emphasis on developing the mental strength and stamina of individuals. On the other hand, Hawawini (2005) states that their teaching needs to focus on 'societal skills', which, according to him, include the need for new paradigms of business thought and consideration of more global issues (Rayment and Smith, 2010). The research by Starkey (2008) indicates that business schools should create MBA programs that go beyond offering merely passports for careers in the financial industry, such as hedge funds, private equity, investment banking, venture capital and consulting. According to Bradshaw (2009) business schools need to familiarize their students with the role of business in society. However, it is also worth to observe that this need has already been recognized by some schools and that their teaching has begun to change (Bradshaw, 2009; Holland, 2009). 


\section{Learning approaches}

Within the literature relating to 'learning' in managerial contexts, it is widely agreed that experiential learning provides a useful pedagogy (Kolb, 1984; Cantor, 1997; Maudsley \& Strivens, 2000; Kolb, et al., 2001; Kayes, 2002; Kolb \& Kolb 2005). Rather than having a teacher provide facts and then testing their ability to recall these facts via memorization, Hmelo-Silver (2004) and Rae (2009) prefer problem based learning (PBL), which aims at getting the students apply the knowledge to new situations; when faced with contextualized, structured problems the students are asked to investigate and discover meaningful solutions by using action and impact driven programs like SPEED, a program implemented in $13 \mathrm{UK}$ higher education institutions and funded by the Higher Education Funding Council for England.

With the aim to answer the industry demands for new ways of thinking, there is a general consensus that a novel way of looking at 'entrepreneurship education' would be to focus on method and more business - like (Curtis, Samy, 2014). The method approach avoids processbased teaching and encourages doing while learning - the principles associated with reflective and experiential learning (Kolb, 1984; Silver \& Barrows, 2006). Neck and Green (2011) pointed out that this is "in fact a portfolio or toolkit approach, which with partnership the appropriate provision can be developed to the satisfaction of all stakeholders".

SLIM project approach perceives the enterprise not as a phenomenon but as a fundamental way of seeing, doing and being. Such thinking places the enterprise education at the very heart of society and social learning.

\section{Intellectual property rights protection, sales and export of new products and services}

The significance of business schools' education relating to SMEs' needs is undisputable, as already emphasized above. Furthermore and more precisely, the need for education on intellectual property protection has lately become the focus of many SMEs and business schools. Evidence of heavy emphasis of education on intellectual property comes from the most recognized universities in the United States, such as Carnegie-Mellon University, the John-Hopkins University, Bucknell University, Cornell University, University of Chicago, Brown University, California State University, etc. (Raman, 2004). Results of the "ip4inno" project reveal a lack of IP-trained personnel in average SMEs, which leads to a logical recommendation: to increase intellectual property protection training among SMEs (IEEPI, 2008).

\section{H1: Need for education about intellectual rights exists}

Intellectual capital in the form of intangible asset like knowledge, skills, creativity is extremely important in today's world. A part of this intellectual capital can be protected in the form of legal rights as intellectual property (Kitching and Blackburn, 1998). The need for 
education on intellectual property exists due to enormous contribution of intellectual property to national and state economies. Industries across economies are dependent on adequate enforcement of their patents, trademarks, and copyrights; while on the other hand, consumers use intellectual property protection to ensure purchases of safe products with warranties. It is widely argued that intellectual capital presents an important source of competitive advantage for individuals (Albert and Bradley, 1996).

Following that, one can also say that Intellectual Property Rights (IPR) represent an important contributor to Europe's competitiveness. Patents, trademarks, design rights and copyrights, can serve as incentives for research and development, for innovation, and can help users identify trusted producers (European Commision, 2014). Intellectual rights can be protected in formal and informal ways (Kitching and Blackburn, 1998). The formal way involves enforcement of patents, trademarks, and copyrights while the informal way means secrecy, design complexity, time advantage. Studies reveal that a few industries depend on protection of their intellectual capital in a formal way by using patents and copyrights (Silbertson, 1987; IPI, 1993) but that most rely on informal forms of protection as for many SME owners acquiring formal intellectual property requires too much money and a time dependent approach (HM Treasury/DTI, 1998).

H2: Formal forms of intellectual property rights protection positively influence exports and sales of new product and services

H3: Informal forms of intellectual property rights protection positively influence exports and sales of new product and services

The 2004 Commission Report (Commission of European Communities, 2004) warned that "poor implementation of the Lisbon Strategy could have devastating costs for Europe, inhibiting progress and delaying development", which has resulted in a commitment to submit national reform programs to a wider national consensus. To reach the necessary social consensus, the member states were requested to better communicate to their citizens the need for increased participation in LLL by launching extensive communication campaigns and by involving individuals along with national, regional and local social partners (Commission of the European Communities, 2000a. Commission of the European Communities, 2009). The new EU education policy slogan on LLL in the new millennium is packed with rhetoric on high returns emanating from investment in knowledge. Similarly, the political discourse continually outlines the socio-economic value of LLL, while the role assigned to it in the knowledge economy appears distributional, stabilizing and developmental. Namely, it ensures equal learning opportunities for all, regardless of their socioeconomic status and previous educational backgrounds (distributional), permanent adjustment to socio-economic changes through acquiring the necessary skills and knowledge both for integration and remaining in the profession (stabilizing) and meeting the needs of the labor market by enhancing the efficiency of human resources through creating opportunities for constant upgrading of skills and knowledge. 


\section{Methodology}

\section{Data collection}

The data for this study were collected by an online questionnaire sent to a sample of small and medium sized Croatian, Polish and United Kingdom companies as participants in the European 'Lifelong Learning' education and training program Leonardo da Vinci project SLIM (Stimulating Learning for Ideas to Market). The project aims to incorporate a community of 400 small businesses from the Republic of Croatia as the European Union accession country until July 2013, Poland as the recent EU member state and the United Kingdom as the old EU member state. The research was conducted to examine business schools' role in achieving SMEs' management education needs in the Republic of Croatia, the Republic of Poland and the United Kingdom. As part of the innovative entrepreneurial activities in these countries the research emphasis was placed on exploring the importance of education regarding intellectual property rights protection and its fundamental role in stimulating business performance in sales and exports of new products and services. The aim was to identify the appropriate types of support, training and advice that small businesses need and use to improve their business performance. While focusing on doing innovative business, the research idea was to examine the educational needs of SMEs regarding intellectual property rights protection and to better understand its role in different historical contexts and business environments. The comparison with the other two EU member states has spawn an opportunity to enable the Republic of Croatia to maximize its business schools' education potential and to develop better focus on cooperation with SMEs. The research population was devised from the databases of the Croatian Chamber of Economy, Business Innovation Croatian Agency, the Polish Chamber of Commerce and the British Chambers of Commerce. Multiple follow-up phone calls and e-mails were then used to increase the response rate. Out of 380 businesses that completed the survey 213 were from Croatia, and 100 and 67 were from Poland from the United Kingdom respectively.

\section{Pre test}

The initial survey was developed based upon previous measures developed for and used within the refining of the English version of the survey was done before translation. The proposed survey packet was examined and modified by international entrepreneruship researchers, business professionals and translators. The survey instrument was checked for form and meaning equivalence with adjustments being made as necessary (Sperber, Devellis \& Boecleck, 1994).

\section{Questionnaire development}

The questionnaire used in this study was originally developed in English by a team of experts gathered by the Leonardo da Vinci SLIM project. In order to carry out the research in individual countries the questionnaire was translated into national languages: Polish and Croatian. The instrument was translated back to ensure reliability and sent as a pilot study to identify any further weaknesses regarding its design. The pilot study was intended to examine whether the questionnaire was easily comprehensible and ensure that the operational 
measures were applicable for the context of small and medium businesses. After this revision and small changes to the original version the final instrument was sent to the potential respondents.

The structure of the questionnaire included several series of questions/statements with scaled responses and several open-ended questions in order to contextualise the overall experiences of entrepreneurs and/or mangers in the current dynamic environment.

\section{Sample description}

In last 15 years, the SME sector in Croatia as well as in Poland and the United Kingdom has played an increasingly important role in generating new businesses and employment. Their importance in contemporary economy is evident in the number of companies, the number of employees and their contribution to the national gross domestic product. Due to their efficiency and flexibility they rather exploit the niche market while having no intention to compete inside the corporative arena. Most participants in the survey operate in the service sector $(23.8 \%)$ and manufacturing $(20.4 \%)$ which covers more than $44 \%$ of all respondents. Nevertheless the survey managed to include the businesses from a variety of sectors: art, IT, entertainment/hospitality, communication, electronic, transportation, software, healthcare, consulting, finance, non-profit organization and energy. Regarding their size $11.1 \%$ had only 1 employee, $42.7 \%$ between 2 and 10, 31.3\% between 11 and 50 employees, $11.7 \%$ between 51 and 250, while 2.6\% had more than 251 employees. Most of the businesses had participated in the market for more than 10 years (50.6\%), following those with 5-10 years (21.9\%), 2-5 years old (19.7\%), 1-2 years old (3.9\%), and those less than a year old (4.5\%). As many as 17 of the business involved were located in business incubators, 16 in science parks and 7 in designated government areas, while the rest had no specific location.

\section{Findings}

\section{Learning approaches}

In order to identify the appropriate ways to approach business education, respondents were asked which of learning approaches would best suit their employees (see details in Table 1 and Figure 1.)

Table 1. Learning approaches

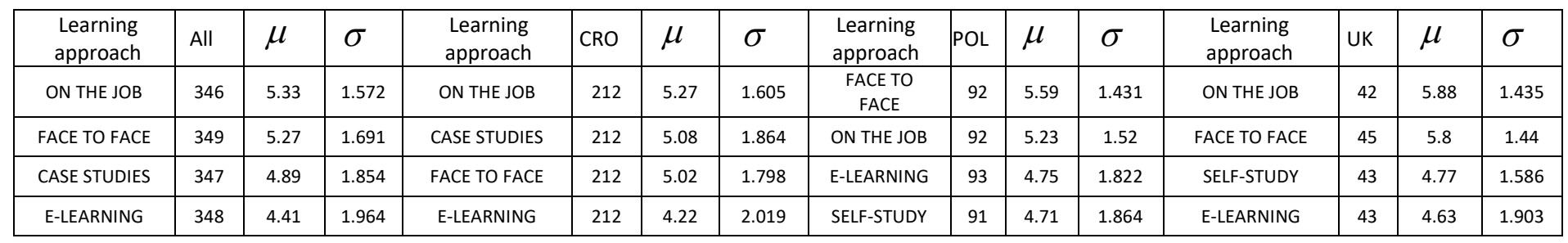




\begin{tabular}{|c|c|c|c|c|c|c|c|c|c|c|c|c|c|c|c|}
\hline SIMULATION & 345 & 4.13 & 1.975 & SIMULATION & 212 & 3.9 & 2.064 & $\begin{array}{c}\text { CASE } \\
\text { STUDIES } \\
\end{array}$ & 94 & 4.66 & 1.864 & CASE STUDIES & 41 & 4.49 & 1.69 \\
\hline SELF-STUDY & 346 & 4.13 & 1.940 & SELF-STUDY & 212 & 3.75 & 1.947 & SIMULATION & 92 & 4.57 & 1.775 & SIMULATION & 41 & 4.37 & 1.771 \\
\hline $\mathrm{N}$ & 340 & & & $\mathrm{~N}$ & 212 & & & $\mathrm{~N}$ & 88 & & & $\mathrm{~N}$ & 40 & & \\
\hline
\end{tabular}

Figure 1. Learning approaches

All Croatia Poland UK

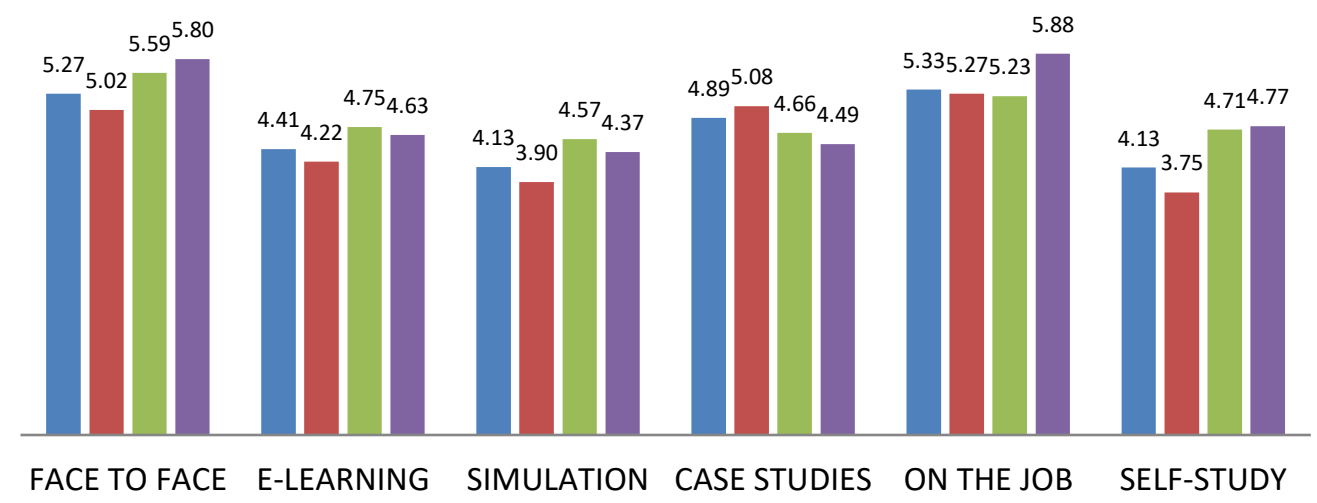

\section{Education and training}

The respondents were asked about the importance of training in particular areas identified in the literature as helping businesses to bring ideas to market. This was done by Likert scale, one being unimportant and seven very important. The most important areas of education identified by Croatian and the UK respondents were: the use of technology, in-house communication, leadership, creativity and innovation, marketing and evaluating opportunity, while the least importance was given to national innovation system (see Figure 2.). On the other hand Polish companies (instead of in house communication) emphasized cooperating with business or scientific partners. Furthermore the methods of intellectual property protection were found to be relatively less important. In the case of Croatia, methods of intellectual property protection was ranked 10 out of 16 different types of education regarding the importance in bringing ideas to market. In the case of Poland this rank was 10 while in the United Kingdom methods of intellectual property protection ranked 12 (see Table 1 in Appendix for more details). These results indicate generally a low level of recognition in prominence of intellectual property protection while bringing ideas to the market.

Next the research examines how often companies actually use various types of intellectual property protection, i.e. formal and informal, or patent and industrial design on the one hand, and secrecy, complexity of design and lead time over competitors on the other. The Likert scale results show lead-time over competitors (5.12) to be the most important way of intellectual property protection for all businesses, following secrecy (4.89) and complexity of design (4.23). Regarding experience with formal ways of protection, $17 \%$ of all respondents claim to have registered patents and $13 \%$ claim to have industrial design protected by intellectual property rights. 
Figure 2. Importance of training/education in bringing ideas to market

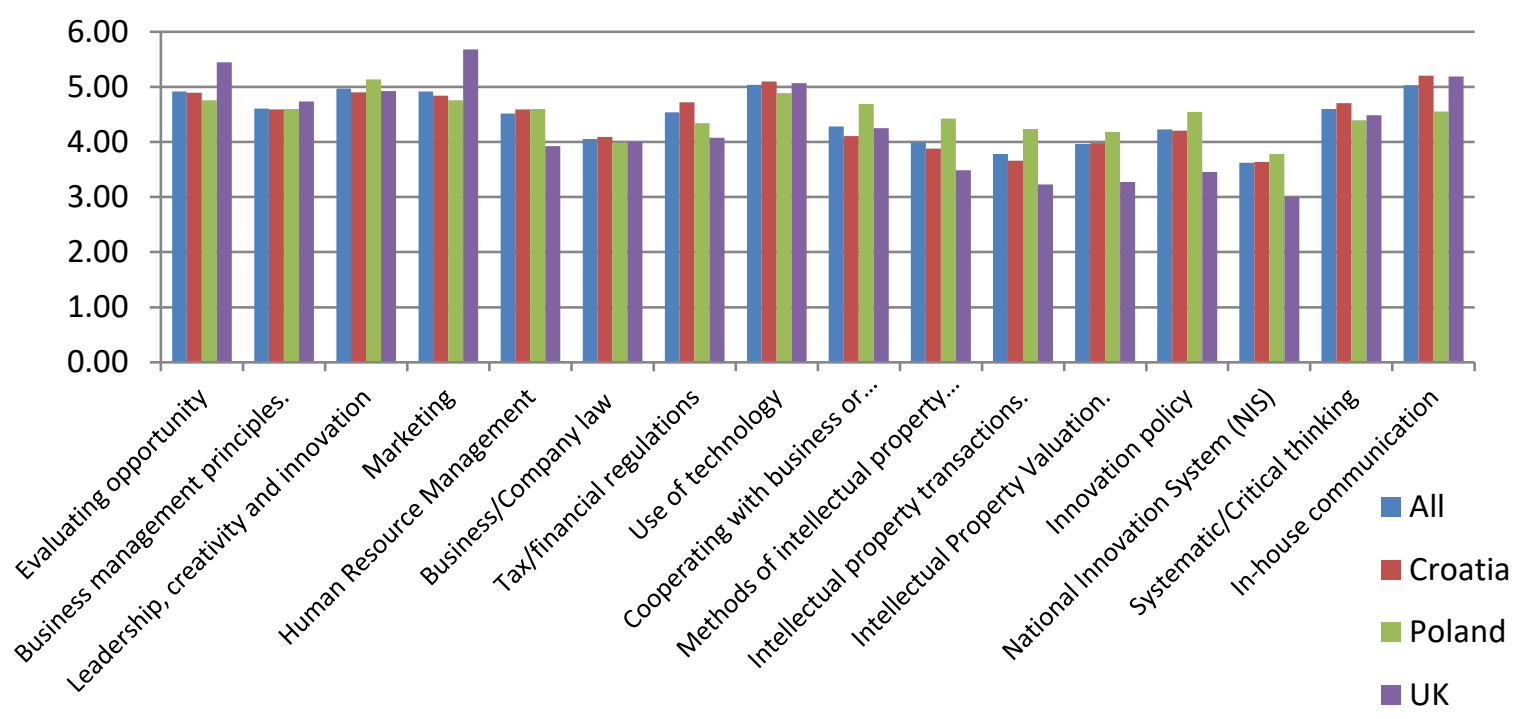

In terms of the level of importance regarding different types of education the paper examines preferences of different businesses regarding the modality of its deliverance. The respondents were asked about the most appropriate way to approach and deliver business education. For Croatian businesses these were: learning on the job, learning based on case studies and face to face learning. The results from Croatia match the results of the entire sample, while the Polish businesses emphasized e-learning together with case study and on the job approach, and UK businesses ranked self-study the highest. The least favorite approaches in Croatia were: selfstudy, simulations and e-learning, while in Poland they were simulations, case studies and self-study, and in the UK they were simulations, learning based on case studies and elearning.

In line with the two following hypotheses of the paper the survey tested the connection between intellectual property rights protection and success in sales and exports of the new products and services.

H2: Formal forms of intellectual property rights protection positively influence exports and sales of new product and services

H3: Informal forms of intellectual property rights protection positively influence exports and sales of new product and services 
Figure 3. The proposed model of influence of informal ways of intellectual property protection and intellectual property rights on sales and exports

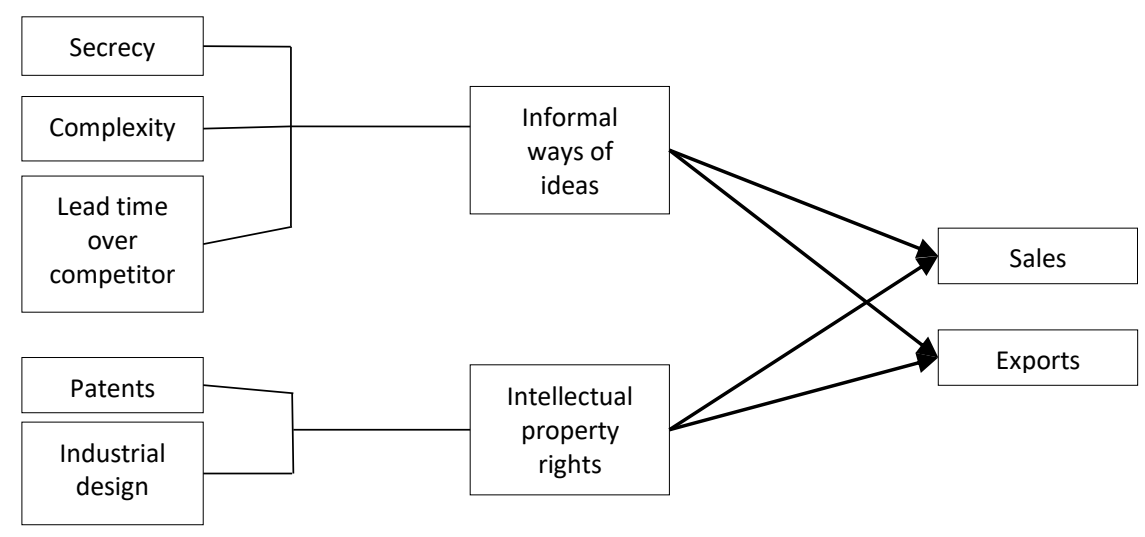

\section{Informal ways of intellectual property protection}

Research found interesting results regarding different informal ways of protecting intellectual property rights. For the entire sample, sales of new products or services were found to be influenced by secrecy, complexity and lead time over competitors, while in the case of exports this was confirmed only for secrecy and complexity. Lead time over competitors was not found significant for exporting activities. Further analysis conducted at the country levels examined the results of each sample individually. Croatia's example matched the results of the entire sample: secrecy, complexity, and lead time over competitors were found significant for sales, while secrecy and complexity were found significant for exporting activities. In the Polish sample secrecy was relevant for sales and complexity for exports. For the UK there was only one significant correlation which identified the connection between complexity of design and sales of new products or services. Therefore, the results show that informal ways of protecting intellectual property rights were found the most important in Croatia, somewhat less in Poland and least in the UK. This may indicate the lack of protection regarding intellectual property rights or deficiency in their law enforcement in the case of Croatia and Poland with regards to UK. More education in the area of intellectual property rights may help improve general business environment and reduce the cost of informal ways of protecting IP on the market.

Table 2. Correlation table: secrecy, complexity of design and lead time over competitors with sales and exports.

\begin{tabular}{|c|c|c|c|c|c|c|c|c|c|c|c|}
\hline \multicolumn{2}{|c|}{ Secrecy*Sales } & \multicolumn{2}{|c|}{ Secrecy*Exports } & \multicolumn{2}{|c|}{ Complexity*Sales } & \multicolumn{2}{|c|}{ Complexity*Exports } & \multicolumn{2}{|c|}{ Lead time*Sales } & \multicolumn{2}{|c|}{ Lead time*Exports } \\
\hline $\begin{array}{l}\text { Correlation } \\
\text { coefficient }\end{array}$ & $p$-value & $\begin{array}{c}\text { Correlation } \\
\text { coefficient }\end{array}$ & $p$-value & $\begin{array}{l}\text { Correlation } \\
\text { coefficient }\end{array}$ & $p$-value & $\begin{array}{l}\text { Correlation } \\
\text { coefficient }\end{array}$ & $p$-value & $\begin{array}{l}\text { Correlation } \\
\text { coefficient }\end{array}$ & $\mathrm{p}$-value & $\begin{array}{l}\text { Correlation } \\
\text { coefficient }\end{array}$ & $\begin{array}{c}\mathrm{p}- \\
\text { value }\end{array}$ \\
\hline 0.135 & 0.033 & 0.205 & 0.001 & 0.166 & 0.010 & 0.252 & 0.000 & 0.198 & 0.002 & 0.096 & 0.117 \\
\hline 248 & & 268 & & 244 & & 262 & & 248 & & 267 & \\
\hline 0.163 & 0.040 & 0.150 & 0.050 & 0.208 & 0.008 & 0.223 & 0.003 & 0.222 & 0.005 & 0.100 & 0.192 \\
\hline 159 & & 170 & & 159 & & 170 & & 159 & & 170 & \\
\hline 0.090 & 0.489 & 0.297 & 0.013 & 0.110 & 0.402 & 0.377 & 0.002 & 0.008 & 0.951 & 0.082 & 0.502 \\
\hline
\end{tabular}




\begin{tabular}{|c|c|c|c|c|c|c|c|c|c|c|c|}
\hline 61 & \multirow{3}{*}{0.468} & 70 & \multirow{3}{*}{0.136} & 60 & \multirow{3}{*}{0.825} & 67 & \multirow{3}{*}{0.762} & 62 & \multirow{3}{*}{0.110} & 70 & \multirow{3}{*}{0.666} \\
\hline 0.143 & & 0.289 & & 0.047 & & 0.064 & & 0.314 & & 0.087 & \\
\hline 28 & & 28 & & 25 & & 25 & & 27 & & 27 & \\
\hline
\end{tabular}

\section{Formal ways of intellectual property protection}

Formal ways of protecting ideas on the market as intellectual property rights were found significant across the entire sample for both patents and industrial design. This was confirmed by in depth analysis on country levels. Croatian companies with registered patents and industrial design were found to have both higher levels of sales and exports of new products or services. In the Polish sample this was true only for patents but the connection was not confirmed in the case of industrial design or for sales or exports. In the UK, sales of new products or services were found to be influential by both patents and industrial design, while patents were not found to be relevant in exporting activities. Although some relationships were not found to be statistically significant, the results verify that companies with registered patents and industrial design were found to have generated higher average rates of sales and exports of new products and services (see Table 2 in Appendix for more details).

Table 3. Significance of formal ways of intellectual property protection regarding sales and exports of new products and services

\begin{tabular}{|c|l|r|r|}
\cline { 3 - 4 } \multicolumn{1}{c|}{} & Sales & Exports \\
\cline { 2 - 4 } ALL & Patents & $\mathbf{0 . 0 0 0}$ & $\mathbf{0 . 0 0 0}$ \\
\cline { 2 - 4 } CRO & Industrial design & $\mathbf{0 . 0 0 1}$ & $\mathbf{0 . 0 0 1}$ \\
\cline { 2 - 4 } & Patents & $\mathbf{0 . 0 0 0}$ & $\mathbf{0 . 0 0 0}$ \\
\cline { 2 - 4 } POL & Industrial design & $\mathbf{0 . 0 0 2}$ & $\mathbf{0 . 0 0 1}$ \\
\cline { 2 - 4 } & Patents & $\mathbf{0 . 0 1 0}$ & $\mathbf{0 . 0 0 0}$ \\
\cline { 2 - 4 } & Industrial design & 0.612 & 0.983 \\
\cline { 2 - 4 } & Uatents & $\mathbf{0 . 0 0 8}$ & 0.182 \\
\cline { 2 - 4 } & Patents & $\mathbf{0 . 1 2 5}$ & N/A \\
\cline { 2 - 4 } & Industrial design & &
\end{tabular}

\section{Conclusion}

All evidence from the three countries involved in the survey shows that the most effective way to deliver sustained and substantial improvements in the outcomes of education efficiency is through sustained and substantial improvements in business school instruction. Having examined the role the business schools in meeting SMEs' management education needs on the basis of the information collected in the Republics of Croatia and Poland, and in the United Kingdom, the sampling facilitated a comparison of countries within different contexts and historical developments. Nevertheless, even though the same numbers of questionnaires were sent in all countries, the number of respondents across countries varied significantly. Thus, Croatia's response rate was the largest with 213 returned questionnaires, while only 100 and 67 questionnaires were returned from Poland and the UK respectively. Consequently, the size of the sample has influenced the variability regarding the different 
types of formal and informal intellectual property rights protection, especially in the case of United Kingdom (with only 67 respondents).

This research has highlighted the identification of entrepreneurial education needs with small and medium-sized businesses in the three EU countries in order to increase innovation activities and research the influence of impacts of intellectual property protection and intellectual property rights on sales and exports. It inspires us to see entrepreneurs who sometimes struggle with embracing the ideas, concepts and different ways of expressing thoughts coming from some education magic injected by scholars. Education in the fields of intellectual property, and knowledge of risk and opportunity evaluation and of the successful ways of using intellectual property in firms is an essential step in fostering their innovative endeavors for Croatia's, Poland's and the UK firms.

Future research should encompass more participants and more countries with different historical backgrounds and at different stages of economic development.

\section{Appendix}

Table 1. Importance of training/education in bringing ideas to market

\begin{tabular}{|c|c|c|c|c|c|c|c|c|c|c|c|c|c|c|c|}
\hline All & $\mathrm{N}$ & Mean & Std & Croatia & $\mathrm{N}$ & Mean & Std & Poland & $\mathrm{N}$ & Mean & Std & UK & $\mathrm{N}$ & Mean & Std \\
\hline 08 & 350 & 5.04 & 1.720 & 016 & 212 & 5.20 & 1.865 & $\mathrm{O} 3$ & 97 & 5.13 & 1.693 & 04 & 41 & 5.68 & 1.524 \\
\hline 016 & 340 & 5.03 & 1.838 & 08 & 212 & 5.10 & 1.778 & 08 & 96 & 4.89 & 1.621 & 01 & 38 & 5.45 & 1.899 \\
\hline $\mathrm{O} 3$ & 347 & 4.97 & 1.734 & 03 & 211 & 4.90 & 1.708 & O4 & 96 & 4.76 & 1.608 & 016 & 37 & 5.19 & 1.913 \\
\hline $\mathrm{O} 4$ & 349 & 4.92 & 1.683 & 01 & 212 & 4.89 & 1.835 & 01 & 95 & 4.76 & 1.687 & 08 & 42 & 5.07 & 1.659 \\
\hline 01 & 345 & 4.92 & 1.808 & O4 & 212 & 4.84 & 1.714 & 09 & 94 & 4.69 & 1.784 & O3 & 39 & 4.92 & 1.979 \\
\hline $\mathrm{O} 2$ & 346 & 4.61 & 1.679 & 07 & 212 & 4.72 & 1.783 & $\mathrm{O} 2$ & 97 & 4.60 & 1.669 & $\mathrm{O} 2$ & 38 & 4.74 & 1.899 \\
\hline 015 & 338 & 4.60 & 1.769 & 015 & 212 & 4.71 & 1.798 & 05 & 94 & 4.60 & 1.498 & 015 & 33 & 4.48 & 1.922 \\
\hline 07 & 349 & 4.54 & 1.793 & $\mathrm{O} 2$ & 211 & 4.59 & 1.649 & 016 & 91 & 4.55 & 1.668 & 09 & 36 & 4.25 & 1.610 \\
\hline 05 & 346 & 4.51 & 1.728 & 05 & 212 & 4.59 & 1.746 & 013 & 94 & 4.54 & 1.657 & 07 & 40 & 4.08 & 1.966 \\
\hline 09 & 342 & 4.28 & 1.789 & 013 & 211 & 4.21 & 1.908 & 010 & 94 & 4.43 & 1.669 & 06 & 40 & 4.00 & 1.935 \\
\hline 013 & 338 & 4.23 & 1.831 & 09 & 212 & 4.10 & 1.797 & 015 & 93 & 4.40 & 1.643 & 05 & 40 & 3.93 & 2.043 \\
\hline 06 & 347 & 4.05 & 1.743 & 06 & 211 & 4.09 & 1.753 & 07 & 97 & 4.34 & 1.701 & 010 & 33 & 3.48 & 1.679 \\
\hline 010 & 339 & 3.99 & 1.841 & 012 & 212 & 3.98 & 1.904 & 011 & 94 & 4.23 & 1.694 & 013 & 33 & 3.45 & 1.583 \\
\hline 012 & 337 & 3.96 & 1.886 & 010 & 212 & 3.88 & 1.908 & 012 & 92 & 4.18 & 1.827 & 012 & 33 & 3.27 & 1.825 \\
\hline 011 & 337 & 3.78 & 1.851 & 011 & 212 & 3.66 & 1.907 & 06 & 96 & 3.99 & 1.651 & 011 & 31 & 3.23 & 1.687 \\
\hline 014 & 333 & 3.62 & 1.809 & 014 & 211 & 3.64 & 1.930 & 014 & 92 & 3.78 & 1.616 & 014 & 30 & 3.00 & 1.339 \\
\hline $\mathrm{N}$ & 312 & & & $\mathrm{~N}$ & 208 & & & $\mathrm{~N}$ & 79 & & & $\mathrm{~N}$ & 25 & & \\
\hline
\end{tabular}

\begin{tabular}{|l|l|}
\hline 01 & Evaluating opportunity \\
\hline 02 & Business management principles. \\
\hline 03 & Leadership, creativity and innovation \\
\hline 04 & Marketing \\
\hline 05 & Human Resource Management \\
\hline 06 & Business/Company law \\
\hline 07 & Tax/financial regulations \\
\hline 08 & Use of technology \\
\hline
\end{tabular}




\begin{tabular}{|l|l|}
099 & Cooperating with business or scientific partners \\
\hline $\mathbf{0 1 0}$ & Methods of intellectual property protection \\
\hline $\mathbf{0 1 1}$ & Intellectual property transactions. \\
\hline $\mathbf{0 1 2}$ & Intellectual Property Valuation. \\
\hline $\mathbf{0 1 3}$ & Innovation policy \\
\hline $\mathbf{0 1 4}$ & National Innovation System (NIS) \\
\hline $\mathbf{0 1 5}$ & Systematic/Critical thinking \\
\hline $\mathbf{0 1 6}$ & In-house communication \\
\hline
\end{tabular}

Table 2. Average value of sales and exports of new products and services in relation to patents and industrial design

\begin{tabular}{|c|c|c|c|c|c|c|}
\hline & & & & & & \\
\hline & & & $\mathrm{N}$ & Patents & $\mathrm{N}$ & Industrial design \\
\hline \multirow{4}{*}{ CRO } & \multirow{2}{*}{ Sales } & Yes & 15 & 4.20 & 17 & 4.00 \\
\hline & & No & 144 & 2.97 & 142 & 2.98 \\
\hline & \multirow{2}{*}{ Exports } & Yes & 16 & 3.94 & 18 & 3.33 \\
\hline & & No & 154 & 2.00 & 152 & 2.05 \\
\hline \multirow{4}{*}{ POL } & \multirow{2}{*}{ Sales } & Yes & 15 & 3.40 & 5 & 3.00 \\
\hline & & No & 48 & 2.71 & 58 & 2.86 \\
\hline & \multirow{2}{*}{ Exports } & Yes & 16 & 3.19 & 6 & 2.18 \\
\hline & & No & 55 & 1.89 & 65 & 2.18 \\
\hline \multirow{4}{*}{ UK } & \multirow{2}{*}{ Sales } & Yes & 2 & 5.00 & 1 & 5.00 \\
\hline & & No & 30 & 2.57 & 31 & 2.65 \\
\hline & \multirow{2}{*}{ Exports } & Yes & 1 & 3.00 & 0 & N/A \\
\hline & & No & 32 & 1.53 & 33 & 1.58 \\
\hline
\end{tabular}




\section{References}

Albert, S. and Bradely, K. (1996) Intellectual Capital as Foundation for new Condition Relating to Organization and Mangement Practices. Open University Business School Research, Working Paper Series 95-15f

Barber M., K. Donnelly and S. Rizvi (2013),"An avalanche is coming. Higher education and the revolution ahead", Institute of Public Policy Research, London

Baron, R. A. (2006) Opportunity recognition as pattern recognition: how entrepreneurs "connect the dots" to identify new business opportunities. Academy of Management Perspective. February, $104 \mathrm{e} 119$.

Benneworth, P.S. (2001), "Academic entrepreneurship and long-term business relationships: understanding 'Commercialization' activities", Enterprise and Innovation Management Studies, Vol. 2 No.3, pp.225-37.

BIS (2010), Innovation and Skills, BIS, available at:, www.bis.gov.uk (accessed 21 February 2014).

Bradshaw, D. (2009) “Perhaps Schools are Partly to Blame?" The Financial Times, 26 January. Available at http://www.ft.com/cms/s/0/b2bf0588-eb49-11dd-bb6e-0000779fd2ac.html \{ accessed $9 / 03 / 14\}$

Cantor, J. A. (1997) Experiential learning in higher education: Linking classroom and community. Washington, D. C.: The George Washington University

Cornuel, E. (2005) The role of business schools in society. Journal of Management Development. Vol.24 No.9 pp 819-829.

Curtis, Lucil; Samy, Martin (2014) "Investigating whether UK business schools need to be more business-like in order to survive in today's dynamic environment", International Journal of Educational Management, Vol. 28 Iss: 6, pp.728 - 750

Darabi, F., Murray, C. (2012) Developing business school/SMEs collaboration: the role of trust. International Journal of Entrepreneurial Behaviour \& Research Vol. 18 No. 4, pp. 477-493

Etzkowitz, H. (2003) Innovation in Innovation: The Triple Helix of University-Industry-Government Relations, Social Science Information 42 (3): 293-338

Etzkowitz, H., M. Ranga, J. Dzisah (2012), "Whither the university? The Novum Trivium and the transition from industrial to knowledge society", Social Science Information, 51, pp. 143-164

European Commision (2014) Evaluation of the European IPR Helpdesk, available online: http://ec.europa.eu/enterprise/policies/industrial-competitiveness/industrial-policy/intellectualproperty-rights/index_en.htm. ISBN 978-92-79-35008-5. DOI: 10.2769/89089

European Commission (2012). Effects and impacts of entrepreneurship programmes in higher education. Brussels, March http://ec.europa.eu/enterprise/policies/sme/promotingentrepreneurship/files/education/effects impact high edu final report en.pdf

Gibb, A.A. (2002) 'In pursuit of a new entrepreneurship paradigm for learning: creative destruction, new values, new ways of doing things and new combinations of knowledge' International Journal of Management Reviews Vol. 4 No. 3 pp 233- 269 
Gibb, Allan; Hofer, Andrea-Rosalinde and Klofsten, Magnus (2013) The Entrepreneurial Higher Education Institution; A Review of the Concept and its Relevance Today. https://heinnovate.eu/intranet/tef/downloads/HEInnovate_Analytical\%20paper.pdf ; accessed June $12^{\text {th }} 2014$.

GRLI (Globally Responsible Leadership Initiative) (2005) A Call for Engagement. Available at http://www.grli.org/images/stories/grli/documents/globally responsible leadership report.pdf $\{$ Accessed 8/01/14

Hawawini, G. (2005) The future of business schools. Journal of Management Development. Vol.24 No.9. pp 770-782.

HM Treasury / DTI (1998) Innovating for the future: Investing in R\&D, HM Treasury / DTI, London

Holland, K. (2009) Is it time to Retrain B-Schools? New York Times. Available at www.nytimes.com/2009/03/15/business/15school.html. \{accessed 9/03/14\}

Hormann, J. (1990) Creative Work: Constructive Role of Business in a Transforming Society. Knowledge Systems Inc.

Intellectual property Institute (IPI) (1993) The Economic importance of Copyright, CLIP, London Ivory, C., Miskell, P., Shipton, H., White, A., Moeslein, K. and Neely, A. (2006) The Future of Business Schools in the UK. Advanced Institute of Management research.

Kaplan, A. (2014) European management and European business schools: Insights from the history of business schools. European Management Journal.

Karthik, R. (2004) Protecting intellectual property rights through information policy. Ubiquity, Vol. 2004 Issue June, pages 1-1

Kayes, D. C. (2002) Experiential Learning and Its Critics: Preserving the Role of Experience in Management Learning and Education. Academy of Management Learning \& Education, 1(2), pp 137149.

Kitching, J. and Blackburn, R. (1998) Intellectual property management in Small and Medium Enterprises (SME). Journal of Small Business and Enterprises Development, Volume 5 Number 4

Kolb, A. Y., \& Kolb, D. A. (2005) Learning Styles and Learning Spaces: Enhancing Experiential Learning in Higher Education. Academy of Management Learning \& Education, 4(2), pp 193-212.

Kolb, D. (1984) Experiential learning: Experience as the source of learning and development. Englewood Cliffs: Prentice-Hall

Kongkiti Phusavat, Suphattra Ketsarapong, Keng-Boon Ooi, Stacy H.P. Shyu, (2012) "Sustaining higher education reforms: Knowledge and policy implications learned from Thailand", International Journal of Educational Management, Vol. 26 Iss: 3, pp.284 - 301

Marzo-Navarro, M., Pedraja-Iglesias, M. and Rivera-Torres, P. (2009) "The marketing approach in relationship between universities and firms”, Journal of Relationship Marketing, Vol. 8 No. 2, pp. $127-47$.

Maudsley, G., \& Strivens, J. (2000) Promoting professional knowledge, experiential learning and critical thinking for medical students. Medical Education, 34(7),pp 535-544. 
Mintzberg, H. (2005) Managers not MBAs: a hard look at the soft practice of managing and management development. San Francisco: Berrett-Koehler Publishing

Mitroff, I. and Denton, E. (1999) A Spiritual Audit of Corporate America - A hard look at Spirituality, Religion and Values in the Workplace. San Fransisco: Jossey - Bass Inc.

NESTA (2008) "Developing entrepreneurial graduates, putting entrepreneurship at the centre of higher education, National Endowment for Science, Technology and the Arts (NESTA), London

Pfeffer, J. and Fong, C.T. (2002). The end of business schools? Less success than meets the eye. Academy of Management: Learning and Education, Vol.1 No.1, pp 78-96.

Plewa, C., Quester, P. and Baaken, T. (2005) "Relationship marketing and university-industry linkages: a conceptual framework", Marketing Theory, Vol. 5 No. 4, pp. 433-56.

Rae, D. (2009) Connecting entrepreneurial and action learning in student-initiated new business ventures: the case of SPEED. Action Learning: Research and Practice, 6(3), pp 289e303.

Rayment, J., Smith, J. (2013) The current and future role of business schools. Education + Training, Vol. 55 Iss: 4/5, pp.478-494

Shaw, S. and Allen, J.B. (2006) It basically is a fairly loose arrangementyand it works out fine really, Analysing the Dynamics of an Inter-Organisational Partnerships, Sport Management Review, Vol. 9 No. 3, pp. 203-28.

Silbertson, A. (1987) The Economic importance of Patents, CLIP, London

Smith, A. M. J., \& Paton, R. A. (2014) Embedding enterprise education: A service based transferable skills framework, The International Journal of Management Education

Sperber, A., Devellis, R., \& Boehlecke, B. (1994) Cross-cultural translation: Methodology and validation, Journal of Cross-Cultural Psychology, 25(4): 501-524.

Starkey, K. (2008) "Business Schools - Look at History to Broaden Your Intellectual Horizons", Financial Times, 20 October. Available at http://www.ft.com/cms/s/0/1bedeabc-9e40-11dd-bdde000077b07658.html \{accessed 9/01/14\}

Vervenne, J.B. (2009) Technology development in the EU-27: In search of the contribution by SMEs. [Powerpoint presentation] private e mail 